УДК:631.46

DOI 10.18101/2587-7148-2019-2-49-56

\title{
БИОГЕННЫЕ СВОЙСТВА ПОЧВЕННОГО ПОКРОВА ПРИ УГЛЕДОБЫЧЕ (НА ПРИМЕРЕ АЗЕЙСКОГО МЕСТОРОЖДЕНИЯ)
}

\section{Е. В. Напрасникова}

\section{(C) Напрасникова Елизавета Викторовна}

кандидат биологических наук, старший научный сотрудник Институт географии им. В. Б. Сочавы СО РАН

664033, Иркутск, ул. Улан-Баторская,1, тел. (3952) 42-70-89

E-mail: napev@irigs.irk.ru

\begin{abstract}
Проведено изучение биогенных свойств почвенного покрова нарушенных земель в условиях Восточной Сибири в пространственно-временном аспекте. Объектом детальных исследований служили почвогрунты законсервированного участка Азейского месторождения угля. Основной цель работы - ежегодное наблюдение за состоянием почвенного покрова нарушенных земель, их преобразованием и мерой снижения негативного воздействия на окружающую среду. Установлено, что щелочно-кислотные условия варьируют от слабокислых до слабощелочных. Почвогрунты характеризуются как малообогащенные азотом (от 0,01 до 0,58 \%) и гумусом (от 0,1 до 0,33\%). Биологическая активность почвогрунтов сопоставима с контрольными почвами и относится к среднеактивным, а её трансформация во времени, протекает по прогрессивному типу. Оценка степени фитотоксичности методом биотестирования с семенами высших растений выявила, что почвогрунты не проявляют ингибирующие свойства, однако биомасса проростков семян, уступает контрольной почве. Основные группы микроорганизмов достаточно насыщены как в количественном, так и в качественном отношении, но значительно меньше, чем в контрольной почве. Разнообразно представлены бактерии (спорообразующие формы) и микроскопические грибы, характерные для дерновых подзолистых почв Восточной Сибири, которые толерантны к нейтральным и слабощелочным почвам. Интерпретация результатов биогенных свойств почвогрунтов позволяет охарактеризовать их как удовлетворительные и отнести к эмбриоземам.
\end{abstract}

Ключевые слова: Восточная Сибирь, угольное месторождение, почвогрунты, биологическая активность, фитотоксичность, микробиоценозы.

\section{Для цитирования:}

Напрасникова E. В. Биогенные свойства почвенного покрова при угледобыче (на примере Азейского месторождения) // Вестник Бурятского государственного университета. Биология, география. 2019. № 2. С. 49-56.

\section{Введение}

Территории разработок угольных месторождений занимают значительные пространства, а их влияние на окружающую среду усиливается. Горнотехническая деятельность человека является причиной образования техногенных ландшафтов, в которых почва, как неотъемлемый и незаменимый компонент биосферы, полностью или в значительной степени нарушена. Изучение экологических характеристик почвенного покрова нарушенных земель при угледобы- 
че всегда было и остается актуальной задачей современности. На исследуемой территории в условиях Восточной Сибири (Тулунский район) был проведен экологический мониторинг, целью которого являлось ежегодное наблюдение за состоянием природных сред (в том числе почвенного покрова нарушенных земель), их преобразованием и мерой снижения негативного воздействия на окружающую среду.

В этой связи ключевые задачи сводились к следующему: отбор почвенных образцов в вегетационный период, определение их биологической активности, установление степени фитотоксичности, характеристика микробиоценоза и интерпретация полученных результатов.

\section{Объекты и методы исследования}

Исследуемая территория угольного месторождения «Азейский» находится в Восточной Сибири на западе Иркутской области (Тулунский район). Район является индустриально-аграрным. Основные отрасли - угледобывающая и сельское хозяйство вносят свой вклад в развитие экономики и обеспечения продовольственной безопасности Приангарья. Климат района резко континентальный с продолжительной и холодной зимой. Значительное удаление от морей и океанов обусловило слабое влияние на его климат теплых воздушных масс, но предопределило сильное воздействие Азиатского антициклона. Среднегодовая температура воздуха составляет от - $1,8-3,5^{\circ} \mathrm{C}$, средняя температура января $20,5-22,8{ }^{\circ} \mathrm{C}$, июля от $+15,1-17,3{ }^{\circ} \mathrm{C}$. Годовое количество осадков изменяется в зависимости от высоты местности и составляет около 400 мм в районе Тулуна. На территории Тулунского района широкое распространение получили почвы: дерново-подзолистые, а также серые лесные глееватые и глеевые. Растительный мир представлен характерной для Восточной Сибири тайгой (Атлас. Иркутская область: экол..., 2004).

Площадь нарушенных земель Азейского месторождения угля составляет около 1000 га, что позволяет отнести их к крупноплощадным. Из них 800 га отработано в отвалы и спланировано (Дубынина, 2017). Нарушенная поверхность представляет систему гребней, поднимающихся на 14-16 м. По составу вскрытых пород они относятся к мелкозёмистым (пески, супеси, суглинки, глины).

Объектом детального исследования служили почвогрунты, одного из законсервированных участков горных работ разреза «Азейский». Консервирование эксплуатационной площади было вызвано временной приостановкой угледобычи. Участок занимает Юго-Западную территорию месторождения, который является северным крылом Заазейской впадины. Он отделен от других горных участков отработанными площадями.

Почвенный покров спланированных и выровненных поверхностей представляет собой гетерогенный субстрат, что характерно для любых нарушенных земель. (Андроханов, Курачев, 2010, Напрасникова, 2004). Почвенный покров месторождения представлен почвогрунтами (смесью почвы с горными породами с включением частиц угля), которые характеризуются как малообогащенные азотом (от 0,1 до 0,33 \%) и гумусом (от 1,14 до 7,1\%). Щелочно-кислотные условия субстратов колеблются от слабокислых до слабощелочных. (Воробьева, 
Напрасникова Е. В. Биогенные свойства почвенного покрова при угледобыче (на примере Азейского месторождения)

Власова, 2012). Известно, что особенности химизма изучаемых, почвогрунтов и их токсичные свойства, определяются составом токсичных ионов и их солей. Основными показателями является количественное содержание ионов: $\mathrm{HCO}_{3}$-, $\mathrm{Cl}-, \mathrm{SO}_{4}{ }^{2}$-. Эти сведения важны для определения и интерпретации порога токсичности изучаемых почвогрунтов, особенно при определении фитотоксичности субстратов. Анализы показали, что количественное содержание ионов в почвогрунтах низкое, так как не достигает порога токсичности (Базилевич, Панкова, 1968). На выровненной поверхности законсервированного участка преобладают: осиново-березовые леса с разнотравно-хвощево-злаковой травяной фитомассой; сосновые леса с осиной и березой с высокотравным злаково-костяничным сообществом, а также разнотравно-злаковые и разнотравно-бобово-злаковые луга (Дубынина, 2017).

Образцы почв и почвогрунтов отбирались согласно общепринятым методикам (Методы почв..., 1991). Показатели рН почв установлены потенциометрическим методом. Для определения биологической активности почвогрунтов был использован экспресс-метод Т. В. Аристовской, М. В. Чугуновой (1989), который является биодиагностическим и высокоинформативным. Сущность метода состоит в определении скорости (в часах) изменения рН индикатора от выделяемого аммиака при разложении карбамида, как суммарного результата биохимической деятельности почвенной микрофлоры и отчасти растительности. Фитотоксичность почвогрунтов определена методом прорастания семян высших растений. В качестве тест-объекта служили мелкие семена редьки в соответствии с методическими указаниями (Методы почв..., 1991). По ингибированию прорастания испытуемых семян (в \%) судили о степени фитотоксичности почвенных субстратов. Микробиологический анализ выполнен путем высева на стандартные питательные среды по общепринятым методикам (Методы почв..., 1991).

\section{Результаты и обсуждение}

Результаты исследований биологической активности почвогрунтов (БАП) участка консервации в разные годы представлены графически на рис. 1. Уровень БАП за период наблюдения (2010-2013 гг.) значительно менялся на всех почвенных разрезах. Чем меньше скорость разложения карбамида, тем выше степень активности испытуемого субстрата. Так, пределы её колебаний составили от 7,5 до 16,5 часов. При этом размах колебаний показывает 9 ч. Такие изменения связываем с гидротермическими факторами. Контрольные почвы природных рубежей не явились исключением, но показали меньшую вариабельность. Значения БАП изменялись от 9,5 до 14 часов, размах колебаний составил 4,5. Сравнительный анализ показал, что БАП нарушенных земель неустойчива, но вполне сопоставима с контрольной. Значения БАП законсервированного участка (за редким исключением: рис.1 - т. 1; 4; 19), можно отнести к среднеактивным. Следует отметить, что рассмотренная БАП, по своей биохимической сущности полифункциональное явление, так как, показывает возможность существенного вклада уреазной активности почвогрунтов в эмиссию углекислого газа. 


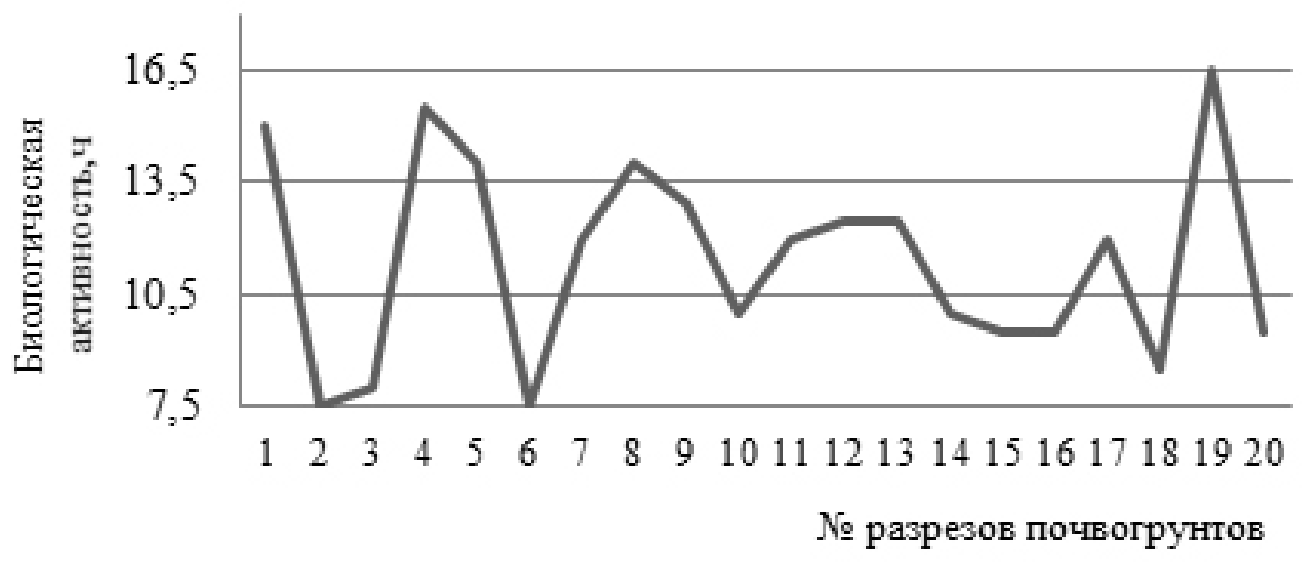

Рис. 1. Уровень биологической активности нарушенных земель законсервированного участка месторождения «Азейский» (слой - 0-10 см).

Примечание: номера разрезов по годам - 1-7 - 2010; 9-11 - 2011; 13-15 - 2012;

17-19 - 2013 гг; разрезы: 8; 12; 16; 20 — контрольные (фоновые).

Наряду с природными токсическими продуктами, в окружающую среду промышленных районов поступают разные по составу и свойствам техногенные загрязнители. Трудности диагностики не позволяют четко дифференцировать эти вещества и определять степень их влияния на отдельные компоненты окружающей среды. В связи с проблемами их прямого определения, в познании ингибирующей функции почвы, используются косвенные методы. Речь идет об оценке степени фитотоксичности по биотестам - семенам высших растений. Результаты этих определений в лабораторных условиях представлены на рис. 2 . Не смотря на то, что преобладающее

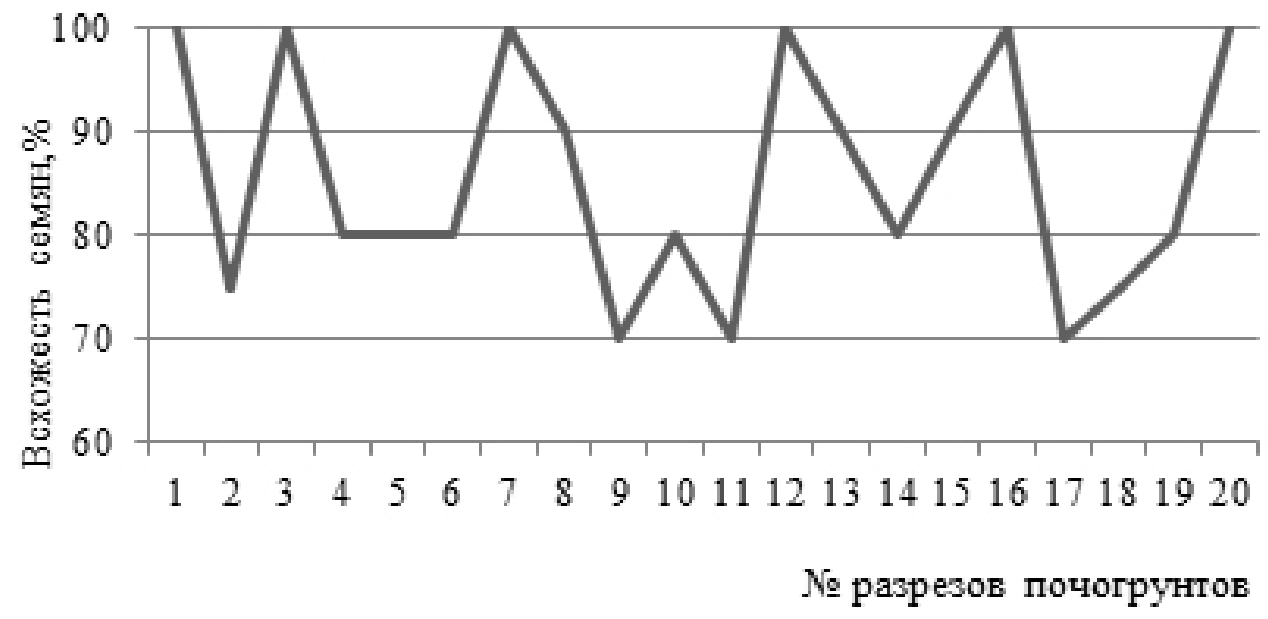

Рис. 2. Степень фитотоксичности нарушенных земель законсервированного участка месторождения «Азейский».

Примечание: номера разрезов по годам такие же, что на рис.2. 
Напрасникова Е. В. Биогенные свойства почвенного покрова при угледобыче (на примере Азейского месторождения)

количество испытуемых почвогрунтов показали отсутствие фитотоксичности, некоторые из них (т. 9; т. 11; т. 17), в отдельные годы, приблизились к порогу токсичности. Данный факт связываем с гидротермическими факторами и отчасти с присутствием токсичных ионов и их солей, которые могут проявляться от свойств почвенного покрова: состава, увлажненности, видов произрастающей растительности, наличия тяжелых металлов.

Кроме всхожести семян дополнительным показателем явилась биомасса проростков в лабораторных условиях. Данные представлены графически (см. рис. 3). Кривая четко показывает тренд постепенного убывания показателей

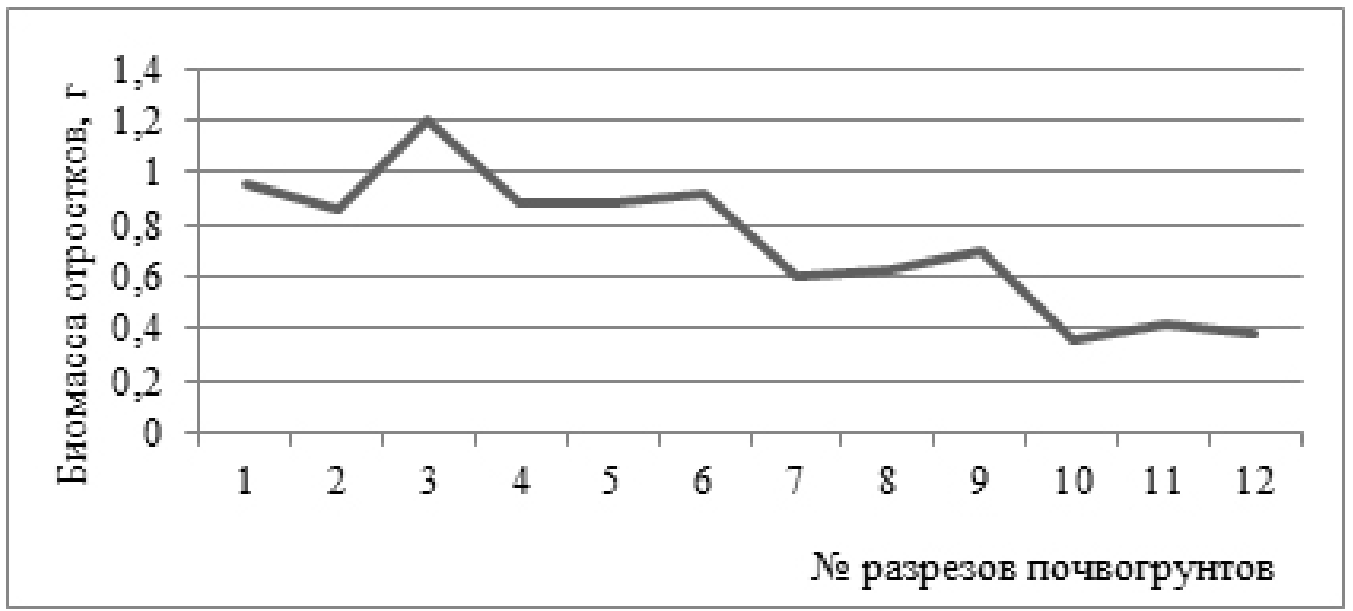

Рис.3. Биомасса проростков испытуемых семян нарушенных земель законсервированного участка месторождения «Азейский»

Примечание: номера разрезов по годам - 1-3 (2010); 4-6 (2011); 7-9 (2012); 10-12 (2013).

по годам наблюдения. Биомасса проростков имеет достаточное сходство между собой, но только внутригодичное. Сравнение результатов опытных почвогрунтов с контрольной почвой, выявило, что они уступают (по биомассе отростков) почти в два раза. Степень фитотоксичности такой картины не показала, за исключением результатов в 2011 году, который был засушливым, в отличие от других лет. Причинами различий показателей по годам, можно считать гидротермический фактор и малообогащенность почвогрунтов биогенными элементами.

Изучение биогенных свойств почвогрунтов было бы не полным без исследования незаменимого и неотъемлемого компонента - почвенно-микробного комплекса. Известно, что экологическая значимость микробиоты состоит в том, что она не просто обитатель, а созидатель почв. Иными словами, биологическая активность почв или почвоподобных субстратов зависит от полифункциональной деятельности микробиоты, как участников почвообразования.

На репрезентативных разрезах были отобраны образцы почвогрунтов в верхних биологически активных слоях. Результаты анализов представлены в таблице. Как количественные, так и качественные показатели, были вполне ожидаемы и сопоставимы с техногрунтами нарушенных земель в других регионах Сиби- 
ри (Напрасникова, 2004, Шергина и др., 2015). Качественный состав эубактерий представлен в основном бациллами и псевдомонадами. Доминируют: Род Bacillus: B. cereus, B. mesentericus-subtilis, B. mycoides; Род Pseudomonas. Актиномицеты однообразны и представлены белыми и серыми цветовыми линиями секций Albus и Cinereus.

Таблица

Численность микроорганизмов нарушенных земель законсервированного участка (млн. КОЕ* /г почвы), слой - $0-10$ см

\begin{tabular}{|l|c|c|c|}
\hline \multirow{2}{*}{$\begin{array}{c}\text { № } \\
\text { образца }\end{array}$} & $\begin{array}{c}\text { Аммонифицирующие } \\
\text { бактерии на мясо- } \\
\text { пептонном агаре }\end{array}$ & $\begin{array}{c}\text { Актиномицеты } \\
\text { на Крахмало- } \\
\text { ммиачном агаре }\end{array}$ & $\begin{array}{c}\text { Микромицеты } \\
\text { на сусло-агаре }\end{array}$ \\
\hline 1 & $0,6 \pm 0,1$ & $0,11 \pm 0,01$ & $0,01 \pm 0,001$ \\
\hline 2 & $0,9 \pm 0,1$ & $0,15 \pm 0,01$ & $0,02 \pm 0,002$ \\
\hline 3 & $1,1 \pm 0,12$ & $0,23 \pm 0,02$ & $0,03 \pm 0,003$ \\
\hline $\begin{array}{l}\text { Контроль, дерновая } \\
\text { лесная оподзол. почва }\end{array}$ & $2,1 \pm 0,23$ & $0,51 \pm 0,05$ & $0,06 \pm 0,006$ \\
\hline
\end{tabular}

*колониеобразующие единицы

Доминируют в почвенном покрове толерантные к нейтральным и слабощелочным значениям $\mathrm{pH}$ микроскопические грибы родов: Fusarium, Aspergillus, Penicillium тоже время в контрольной почве, кроме вышеуказанных, обнаружены роды: Alternaria, Muсоr.

\section{Заключение}

Биодиагностические принципы, с использованием индикационных методов и выбором интегральных показателей, позволили выявить биогенные свойства почвенного покрова нарушенных земель при открытой добыче угля и их функциональные особенности в пространственно-временном аспекте. Отмечена тенденция увеличения биологической активности почвогрунтов, что характеризует развитие сложных биохимических процессов по прогрессивному типу. Этому способствуют нетоксичность отвальных пород вскрышной толщи, оптимальное соотношение тепла и влаги в вегетационный период, наличие разнообразного и активного микробного комплекса, включающего в себя все основные систематические группы. Совокупность результатов по долгосрочному исследованию биогенных свойств почвогрунтов законсервированных участков позволяет отнести их к эмбриозёмам.

Таким образом, в результате продолжительных исследований сложных почвенно-биохимических процессов, выявлена их направленность, установлена структурно-динамическая характеристика микробиоценозов, показана нетоксичность субстратов для произрастания растений. В целом, биогенные свойства почвенного покрова законсервированных участков угольного разреза «Азейский», в реальном времени можно охарактеризовать как удовлетворительные. 
Напрасникова E. В. Биогенные свойства почвенного покрова при угледобыче (на примере Азейского месторождения)

\section{Литература}

1. Андроханов В. А., Курачев В. Н. Почвенно-экологическое состояние техногенных ландшафтов: динамика и оценка. Новосибирск: Изд-во СО РАН, 2010. 224 с.

2. Аристовская Т. В. Чугунова М. В. Экспресс-метод определения биологической активности почв // Почвоведение, 1989. №11. С. 142-147.

3. Атлас. Иркутская область: экологические условия развития. М.-Иркутск, 2004. C. $76-77$.

4. Базилевич Н. И Панкова Е. И Опыт классификации почв по засолению // Почвоведение, 1968. №11. С. 3-15.

5. Воробьева И. Б., Власова Н. В. Геохимическая оценка земель, нарушенных при открытой разработке буроугольного разреза, в условиях Восточной Сибири // Известия Оренбургского государственного аграрного университета. 2012. № 4. С. 125-132.

6. Государственный доклад о состоянии и об охране окружающей среды Иркутской области в 2011 г. Иркутск: Изд-во ООО «Форворд», 2012. 400 с.

7. Дубынина С. С. Пространственно-временные изменения надземной в экосистемах отвалов после угледобычи // Успехи современного естествознания. 2017. № 9. С. 57-62.

8. Методы почвенной микробиологии и биохимии / Под ред. проф. Д. Г. Звягинцева. М.: МГУ, 1991. 303 с.

9. Напрасникова Е. В. Реакция биотического компонента почвы на техногенное воздействие (долгосрочный эксперимент) // Тренды ландшафтно-геохимических процессов в геосистемах юга Сибири. Новосибирск: Изд-во «Наука», 2004. С. 121-128.

10. Шергина О. В., Михайлова Т. А., Калугина О. В., Пройдакова О. А. Естественное восстановление почвенного и растительного покрова на промышленных отвалах // География и природ. ресурсы. 2015. № 2. С. 66-74.

\section{BIOGENIC PROPERTIES OF SOIL COVER DURING COAL MINING (A CASE STUDY OF THE AZEISKII DEPOSIT)}

\section{E. V. Naprasnikova}

\section{Naprasnikova Elizaveta Viktorovna}

Cand. Sci. (Biol.) senior researcher, ass. prof.

Sochava Institute of Geography SB RAS 1, Ulan-Batorskaya, st., Irkutsk, 664003

tel.: (3952) 42-70-89 e-mail: napev@irigs.irk.ru

A study was made of the biogenic properties of soil cover of disturbed lands in the settings of Eastern Siberia from the spatio-temporal perspective. The objective of detailed investigations was to examine the soils and grounds of the temporarily closed-down area of the Azeiskii coal deposit. The focus of the research was on annual observations of the status of soil cover, its transformation and on the measures for reduction in the negative influence on the environment. It is established that the acid-alkaline conditions vary from weakly acidic to weakly alkaline. The soils and grounds are characterized as low-enriched with nitrogen (from 0.01 to $0.58 \%$ ) and humus (from 0.1 to $0.33 \%$ ). Biological activity of soils and grounds is comparable with benchmark soils and refers to moderate activity, and their transformation across time occurs according to the progressive type. An assessment of the degree of biotoxicity by biotesting with seed of higher plants showed that the soils and grounds do not exhibit any inhibiting properties; however, the biomass of the germinated seeds is inferior to the benchmark soil. The main groups of microorganisms are sufficiently 
saturated both quantitatively and qualitatively but to a considerably lesser extent that are in the benchmark soil. There is a diversity of bacteria and microscopic fungi characteristic for soddy podzolic soils of Eastern Siberia which are tolerant to neutral and weakly alkaline soils. Interpretation of the results from investigating the biogenic properties of soils and grounds indicates that they can be characterized as satisfactory and be categorized as embryozems.

Keywords: Eastern Siberia, coal deposit, soils and grounds, phytotoxicity, microbiocenoses. 